\title{
REPRODUCTIVE TOXICITY AND ENDOCRINE DISRUPTION OF ORAL AND DERMAL EXPOSURE TO PESTICIDE MIXTURE IN MALE RATS
}

Naglaa F. Mahmoud ${ }^{1}$; Hanaa A. El-Hallawany ${ }^{2}$; Eman Mohamed $^{3}$; Dina Glal ${ }^{3}$ and Amr A. Abd Allah ${ }^{4}$

${ }^{1}$ Department of Forensic Medicine and Clinical Toxicology, Cairo University, Egypt ${ }^{2}$ Pathology Department, ${ }^{3}$, biotechnology department, (ARRI)Elharam -Giza, Egypt

${ }^{4}$ Mammalian Toxicology Departments, Central Agricultural Pesticides Lab. (CAPL), Egypt

\begin{abstract}
The current study was performed to assess the risk and hazards of oral \& dermal exposure to chlorpyrifos \& cypermethrin mixture based on some reproductive \& endocrine impaired parameters as well as histopathological alterations \& histomorphometric study. Eighty-five Wister male rats (weighing 130-150g) were randomly classified into four groups (a, b, c and d). Each of group (a) and (b) were further subdivided into 5 subgroups used for determination of the oral and dermal LD50. While group (c) and (d) were classified into 3 subgroups which were used for oral and dermal treatments respectively. The first subgroups of (c) and (d) were considered as control. Rats of two subgroups (c) treated orally by 2 doses $4.26 \mathrm{mg} / \mathrm{kg}$ (1/20 LD50) and $2.84 \mathrm{mg} / \mathrm{kg}(1 / 30$ LD50). Rats of two subgroups (d) treated by dermal application of 2 doses $70.85 \mathrm{mg} / \mathrm{kg}(1 / 30 \mathrm{LD} 50)$ and $42.51 \mathrm{mg} / \mathrm{kg}$ (1/50 LD50). The experiment was conducted for 65 consecutive days. The results revealed that, the tested pesticides mixture caused a significant reduction in reproductive organs weights, sperm count, sperm motility percent, alive sperm percent, pseudocholinesterase and serum testosterone levels in all treated groups especially the dermally treated groups $(\mathrm{P} \leq 0.05)$, moreover there was azoospermia in most of the group of rats treated with high dermal dose. The treated groups showed a significant increase in sperm abnormalities and composite score which represent sperm DNA fragmentation. Moderate to severe histopatholoical alterations were detected in testis and epididymis of treated rats in a dose and route dependant manner in the form of germ cell desquamation, multinucleated giant cells formation and leydig cell vacuolization with disturbance in spermatogenesis. Moreover the histomorphometric parameters analysis detected significant $(\mathrm{P} \leq 0.05)$ reduction of diameter, thickness, endothelium height $\&$ lumen of seminiferous tubules and also significant reduction of sertoli cell population. There was significant increase of blood vessel wall thickness. These results indicated that the tested formulation had synergistic effects and induced significant harmful effects on male reproductive system which were more pronounced with dermal exposure.
\end{abstract}

Key words: chlorpyrifos, cypermethrin, reproductive toxicity, male rats, testosterone, Histomorphometry.

\section{INTRODUCTION}

Pesticides are a key element of pest management programs in modern agriculture to increase the levels of production (Repetto \& Baliga, 1996). The use of insecticide 
combinations in agricultural pest control is on the increase due to the challenges posed by insecticide resistance to the existing chemicals .Thus the use of pesticides mixtures has been increased in developing countries (Committee on Toxicity of Chemicals, 2002) which necessitated accurate identification of their potential hazards to human and animal health (Bolognesi, 2003).

The potentiated effects of pesticides mixtures were studied for atrazine, chlorpyrifos and chlorothalonil (DeLorenzo \& Serrano, 2003)as well as cypermethrin, quinolphos and linuron (Chauhan et al., 2005) indicated that pesticide mixtures showed an increase in the frequency of toxicities and damage. The emphasis on the exposure by the oral route does not generally apply to workers that are exposed primarily by the dermal route through handling pesticides or re-entering treated fields (Shadnia et al., 2007) \& (John et al., 2001).

This study was performed to determine the hazards of a new pesticide formulation (Clorthan 29\% EC) which is locally made and w assaled as pesticide ready to use in agricultural pest control in Egypt. Study the toxicity of this new mixture is mandatory for its hazards identification. The pesticide formulation consists of two traditional pesticides chlorpyrifos and cypermethrin.

Cypermethrin is a class of synthetic pyrethroids which have many applications in agriculture, medicine, and veterinary practices. Exposure to pyrethroids has increased recently due to regulatory restrictions on other insecticides usage, its high efficacy against target species and their relatively low mammalian toxicity and rapid biodegradation (Power \& Sudakin, 2007).

Exposure to cypermethrin caused ill health effects such as severe giddiness, neonatal deaths, skin and eye disorders and congenital defects. Cypermethrin can also cause a range of neurotoxic, genotoxic, immunotoxic effects and reproductive toxicity in many experimental systems (Yousef et al., 2003a).In addition, (Yousef et al., 2003b). showed that cypermethrin has pronounced effects in several physiometabolic functions including body weight, food intake, testosterone level and reproductive health of male rabbits. Cypermethrin is considered one of the most common contaminants in the ecosystem.

CPF (Chlorpyrifos)is the most frequently studied OP compound, due to its large application in crop protection and also its wide applications in households. Its metabolite, 3,5,6-trichloro-2-pyridinol is the most commonly detected pesticide degradation product in urine of the general population, reflecting wide human exposure to CPF (Ojha et al., 2011). OP exposure could affect the immune system (Galloway \& Handy, 2003), Hematological system (Jintana et al., 2009), and reproductive system (Jintana et al., 2009). OP pesticides have demonstrated genotoxic, alkylating and clastogenic properties; thus they are potentially mutagenic and clastogenic (Mehta et al., 2008). The main mechanism of action of CPF is its inhibition of acetylcholinesterase (AChE) leading to induction of neurotoxicity through accumulation of the neurotransmitter, acetylcholine (ACh) at the nerve endings and the 
neuromuscular junctions (Ambali \& Aliyu, 2012). Other mechanism independent of $\mathrm{AChE}$ inhibition is the pesticides induced-Oxidative stress effects (Eaton et al., 2008). Most of poisonings occur in developing countries due to weak safety programs, minimal use of protective equipment, absence of washing facilities, poor labeling, and lack of information programs and public health awareness (Ramos et al., 2010). Recently, there has been increasing concern regarding the influence of pesticides and manmade chemicals on the normal function of endocrine systems. Since hormones are involved in fundamental functions of an organism (Endocrine Disruptor and Testing Advisory Committee, 1998).

The interaction between OPs and pyrethroids is relatively well known, the non-reversible inhibitory effect on esterases by OPs also affect the activity of enzymes responsible for breaking of the ester bond of the pyrethroid molecule (Latuszynska et al., 2001). Normally, the ester bond is rapidly metabolized in mammals, the products of which are non-active and rapidly excreted from the body mainly through the urine. Blocking the hydrolysis of pyrethroids significantly abolish the metabolism of these pesticides, therefore, a stronger insecticidal effect of the OP-pyrethroid mixture is observed (Timchalk et al., 2005).

\section{AIM OF THE WORK}

This study was conducted to assess the risk and hazards of oral \& dermal exposure to chlorpyrifos \& cypermithrin mixture on some reproductive and endocrine parameters as well as histopathological alterations \& histomorphometric study.

\section{MATERIALS \& METHODS}

\section{Chemicals}

The pesticide formulation used in this work was a mixture consisted of two active ingredients cypermethrin $5 \%$, the IUPAC name: (RS) - $\alpha$-cyano3-phenoxybenzyl (1RS, 3RS; 1RS, 3SR)-3-(2,2-dichlorovinyl)-2,2-

dimethylcyclopropanecarboxylate and chlorpyrifos $24 \%$, the IUPAC name: (O,O-diethyl O-3,5,6 trichloro-2pyridyl phosphorothioate) . This mixture was supplied as an emulsifiable concentrate (EC) from the Department of Mammalian and Aquatic Organisms Toxicity Research, Central Agricultural Pesticides Lab, Dokki, Egypt. A stock solution (10\%) of the formulation was prepared in corn oil and was used throughout the oral treatments .For the dermal treatments it was applied without dilution.

\section{Animals}

85 adult male wister rats weighing 130-150g were obtained from the laboratory animal house of the Modern Veterinary Office, Giza, Egypt. Animals were kept under full hygienic conditions, had free access to fresh water and fresh well-balanced food, the animals were acclimatized 2 weeks prior to the experiments.

\section{Study Design}

Rats were randomly classified into four groups (a, b, c and d). Each of group (a) and (b) were further subdivided into 5 subgroups used for determination of the oral and dermal LD50. While group (c) and (d) were classified into 3 subgroups which were used for oral and dermal treatments respectively. The first subgroups of (c) and (d) were considered as control. Rats of two subgroups (c) treated orally by 2 doses $4.26 \mathrm{mg} / \mathrm{kg}$ (1/20 LD50) and $2.84 \mathrm{mg} / \mathrm{kg}(1 / 30 \mathrm{LD} 50)$. Rats of 
two subgroups (d) treated by dermal application of 2 doses $70.85 \mathrm{mg} / \mathrm{kg}(1 / 30$ LD50) and $42.51 \mathrm{mg} / \mathrm{kg}$ (1/50 LD50). The experiment was conducted for 65 consecutive days, taking into consideration the period necessary to complete a spermatogenic cycle (Clermont \& Harve, 1965).

Calculation of the median lethal dose

Different four concentrations were given for the assigned groups and Mortality was assessed and counted in the different groups .The oral and dermal LD50 were calculated by using classical method according to (Weil, 1952).

\section{Blood samples collection}

Rats were $s$ anaesthetized by ether and sacrificed by cutting of the neck veins at the end of the study. Blood samples were collected and placed immediately in ice. The blood was centrifuged with $3000 \mathrm{rpm}$ for $10 \mathrm{~min}$. to separate the serum. Whichwas kept frozen at $-20^{\circ} \mathrm{C}$.

\section{Evaluated parameters:}

\section{- Reproductive organs weights}

Body weight was registered weekly during the study period. After animal dissection, the testes, epididymes and accessory sex organs (seminal vesicles and prostate glands) were removed, grossly examined and weighed. The index weight (I.W.) was calculated as I.W. = organ weight $(\mathrm{g}) / 100 \times$ body weight (g) (Matousek, 1969 ).

\section{- Epididymal sperm count}

Epididymal spermatozoa count was obtained by using a modified method of Yokoi (Yokoi et al., 2003). The epididymis was minced in 5 mlof saline, placed in a rocker for $10 \mathrm{~min}$ then incubated at room temperature for $2 \mathrm{~min}$. The supernatant fluid was diluted $1: 100$ by a solution formed of $5 \mathrm{~g}$
$\mathrm{NaHCO} 3,1 \mathrm{ml}$ formalin $(35 \%)$ and $25 \mathrm{mg}$ eosin per $100 \mathrm{ml}$ distilled water. About10 $\mu$ l of the diluted semen was placed in the counting chamber of the improved Neubaur haemocytometer (Deep 1/10mm, LABART, Munich, Germany) and was allowed to stand for $5 \mathrm{~min}$ for counting under a light microscope at $\times 200$ magnification.

\section{- Epididymal alive sperm percent}

By using a drop of epididymal contents and mixing it with an equal drop of eosin-nigrosin stain allowing the semen to be mixed with the stain and a thin film was spread on a clean slide. Two hundred sperms were randomly examined per slide at $\times 400$ magnifications (Bearden, 1980).

\section{- Sperm motility}

Sperm-progressive motility was determined microscopically immediately within 2-4min of their isolation from the cauda epididymis (SöNnmez et al.,2005) . Fluid was obtained from the cauda epididymis with a pipette and diluted to $2 \mathrm{ml}$ with tris buffer solution. The percentage of motility was evaluated at $\times 400$ magnification.

\section{- Sperm abnormalities}

A total of 300 sperm was counted on each slide under light microscope at $\times 400$ magnification. The percentages of morphologically abnormal spermatozoa (detached head and coiled tail) were counted (Evans \& Maxwell,1987).

\section{- Determination of serum testosterone levels:}

The blood samples were collected in the morning to minimize the diurnal hormonal variations. Serum was separated for determination of the total serum testosterone by using solid phase radioimmunoassay (RIA) kits. Which 
depend on testosterone-specific antibody immobilized to the wall of a polypropylene tube (Demetrious, 1987).

\section{- Determination of Plasma cholinesterase}

Plasma cholinesterase or butyrylcholinesterase (BuChE) activity was estimated The used mixture containing $2.6 \mathrm{ml}$ sodium phosphate buffer $(0.1 \mathrm{M}, \mathrm{pH} 7.5), 0.15 \mathrm{ml}$ of DTNB (dithio-bis-2-nitrobenzoic acid, $10 \mathrm{mM}, \mathrm{pH}$ 7.0; containing $3 \mathrm{mg}$ $\mathrm{NaHCO} 3$ per $8 \mathrm{mg}$ DTNB) and $0.1 \mathrm{ml}$ plasma was incubated at room temperature for $10 \mathrm{~min}$. Reaction was started by addition of $0.15 \mathrm{ml}$ acetylthiocholine iodide $(12.5 \mathrm{mM})$ and absorbance change per min was recorded at $412 \mathrm{~nm}$ for $4 \mathrm{~min}$. (Ellman et al., 1961).

\section{- Genotoxic investigation: \\ Sperm collection:}

Spermatozoa were isolated from vas deferens in PBS ( $\mathrm{Ca}$ and $\mathrm{Mg}$ free) and incubated for $5 \mathrm{~min}$ to allow the spermatozoa to disperse then examined for motility and stored at $-70^{\circ} \mathrm{C}$ until the performance of comet assay.

\section{Detection of DNA damage using}

\section{Comet Assay:}

DNA damage in spermatozoa was detected using the comet assay as described by (Codrington et al., 2004). Which depend on a method previously described by (Singh et al. 1989) \& (Haines et al., 1998) with few modifications. The frozen sperm samples were thawed at $37^{\circ} \mathrm{C}$, and then the samples embedded in agarose, followed by cell lysis, DNA unwinding, neutralization and electrophoresis. Then the slides were fixed with ice cold absolute ethanol for 10 min. All subsequent steps will be done in dark to prevent any further
DNA damage and the slides were kept in dark humid box till examination. Before visualization the slides were stained immediately with $50 \mu \mathrm{l}$ of 20 $\mu \mathrm{g} / \mathrm{ml}$ ethedium bromide, and visualized with Leica epifluorescent microscope (Green filter: N2.1 with Exitation filter: BP 515-560, Dichromatic Mirror: 580, Suppression filter: LP 590), the images for the sperm nuclei were digitalized with Leica DFC camera. DFC 280 supplied with Leica DFC Twain software with Host application program Imaging $®$ to view and capture digital images. 100 sperm nuclei were scored for each sample. The sperm comets were visually scored (Collins et al., 1995) in to five grades from grade 0 (no damage) to grade 4 (extensive damage). Then a composite score was calculated to the individual grade scores for 100 spermatozoa per sample. The composite score was formed by multiplying the number of sperm nuclei by the corresponding numerical scale, thus the composite score could range from 0 (all undamaged) to 400 (all maximally damaged).

\section{- Histopathological studies:}

Histopathological examination: Animals were sacrificed at the end of the study; testes and epidydimes were dissected and immediately fixed in $10 \%$ neutral formalin solution. The fixed specimens were trimmed, washed, dehydrated in ascending grades of alcohol, cleared in xylene and immersed in paraffin. Then the samples were cut at 3-5 $\mu \mathrm{m}$ thickness, stained with $\mathrm{H} \& \mathrm{E}$ stain as well as Massontrichrome stain for showing collagen and elastic fibers changes (Suvarna et al., 2013).

Histomorphometric study:

By using H\&E stainedsections, 
morphometric study measurements of ST (seminiferous tubules) diameter, lumen, germinal epithelial height, blood vessel wall and sertoli cell populations were obtained, expressed in $\mu \mathrm{m}$ at $\mathrm{x} 100$ magnification with a semi automatic system which is formed of a trinocular microscope (Olympus Corporation, Japan), Digimizer program version 2 and personal computer (Toshiba, Japan) (Aiad et al., 2008).

\section{RESULTS}

\section{The results of oral and dermal LD50}

Table (1): median lethal dose (LD50) (oral and dermal)

\begin{tabular}{|c|c|c|c|}
\hline Treatment & $\begin{array}{c}\mathrm{LD50} \\
\mathrm{Mg} / \mathrm{kg}\end{array}$ & \multicolumn{2}{|c|}{ Doses used in the study $(\mathrm{mg} / \mathrm{kg})$} \\
\cline { 3 - 4 } & & Low dose & high dose \\
\hline Oral & 85.16 & $2.34(1 / 30$ LD50) & $4.16(1 / 20$ LD50) \\
Dermal & 2125.03 & $42.21(1 / 50$ LD50) & $70.55(1 / 30$ LD50) \\
\hline
\end{tabular}

The used doses in this study were determined based on the calculated
LD50 as illustrated in table (1) for both oral \&dermal treatments.

\section{Reproductive Organs weights}

Table (2) Effect of the tested pesticides on the reproductive organs weights of the treated rats

\begin{tabular}{|l|c|c|c|c|c|}
\hline \multirow{2}{*}{ Parameter } & \multicolumn{5}{|c|}{ Groups } \\
\cline { 2 - 6 } & control & $\begin{array}{c}\text { oral low } \\
\text { dose }\end{array}$ & $\begin{array}{c}\text { oral high } \\
\text { dose }\end{array}$ & $\begin{array}{c}\text { dermal low } \\
\text { dose }\end{array}$ & $\begin{array}{c}\text { dermal } \\
\text { high dose }\end{array}$ \\
\hline Testis I.W. & $1.42 \pm .11 \mathrm{c}$ & $\begin{array}{c}1.28 \pm .25 \\
\mathrm{c}\end{array}$ & $1.07 \pm .12 \mathrm{~b}$ & $0.97 \pm .06 \mathrm{~b}$ & $\begin{array}{c}0.78 \pm .14 \\
\mathrm{a}\end{array}$ \\
\hline $\begin{array}{l}\text { Epididymis } \\
\text { I.W. }\end{array}$ & $0.75 \pm .15 \mathrm{~b}$ & $\begin{array}{c}0.62 \pm .11 \\
\mathrm{ab}\end{array}$ & $\begin{array}{c}0.62 \pm .12 \\
\mathrm{ab}\end{array}$ & $0.57 \pm .12 \mathrm{a}$ & $\begin{array}{c}0.48 \pm .11 \\
\mathrm{a}\end{array}$ \\
\hline $\begin{array}{l}\text { Accessory sex } \\
\text { organs I.W }\end{array}$ & $0.73 \pm .13 \mathrm{~d}$ & $\begin{array}{c}0.66 \pm .07 \\
\mathrm{~cd}\end{array}$ & $\begin{array}{c}0.58 \pm .09 \\
\mathrm{bc}\end{array}$ & $0.50 \pm .11 \mathrm{ab}$ & $\begin{array}{c}0.40 \pm .10 \\
\mathrm{a}\end{array}$ \\
\hline
\end{tabular}

Table (2) all values are expressed as mean \pm S.E. Values with different letters at the same raw are significantly different at $\mathrm{P} \leq 0.05$ (ANOVA) with Duncan's multiple range test. I.W. = organ weight $(\mathrm{g}) / 100 \times$ body weight $(\mathrm{g})$.

The obtained data of the high dose orally treated group (1/20 LD50) showed significant reduction of The index weight of testis, epididymis and accessory sex glands $(\mathrm{P} \leq 0.05)$ While the reduction was less pronounced in the low dose orally treated group. The dermal treatments induced highly significant reduction of sex organs weight at high and low doses $(\mathrm{P} \leq 0.05)$. 


\section{Sperm Characteristics}

Table (3): Effect of the tested pesticides on sperm characteristics of male rats

\begin{tabular}{|c|c|c|c|c|}
\hline \multirow{2}{*}{ Parameter } & \multicolumn{4}{|c|}{ Groups } \\
\cline { 2 - 5 } & control & oral low dose & $\begin{array}{c}\text { oral high } \\
\text { dose }\end{array}$ & $\begin{array}{c}\text { dermal low } \\
\text { dose }\end{array}$ \\
\hline $\begin{array}{c}\text { Sperm count } \\
(\mathbf{x 1 0} / \mathbf{m l})\end{array}$ & $165.40 \pm 1.42 \mathrm{~d}$ & $\begin{array}{c}142.08 \pm 13.25 \\
\mathrm{c}\end{array}$ & $\begin{array}{c}131.40 \pm \\
22.42 \mathrm{~b}\end{array}$ & $\begin{array}{c}95.83 \pm 12.01 \\
\mathrm{a}\end{array}$ \\
\hline $\begin{array}{c}\text { Sperm } \\
\text { motility\% }\end{array}$ & $84.60 \pm 2.40 \mathrm{~d}$ & $71.26 \pm 7.45 \mathrm{c}$ & $51.44 \pm 6.29 \mathrm{~b}$ & $44.25 \pm 4.83 \mathrm{a}$ \\
\hline $\begin{array}{c}\text { Sperm } \\
\text { abnormality\% }\end{array}$ & $8.28 \pm 1.42 \mathrm{a}$ & $16.41 \pm 4.40 \mathrm{~b}$ & $21.75 \pm 3.88 \mathrm{c}$ & $27.25 \pm 4.09 \mathrm{~d}$ \\
\hline $\begin{array}{c}\text { Alive sperm } \\
\%\end{array}$ & $94.27 \pm 1.28 \mathrm{~d}$ & $81.75 \pm 3.81 \mathrm{c}$ & $63.01 \pm 8.44 \mathrm{~b}$ & $50.35 \pm 7.88 \mathrm{a}$ \\
\hline
\end{tabular}

All values are expressed as mean \pm S.E. Values with different letters at the same raw are significantly different at $\mathbf{P} \leq \mathbf{0 . 0 5}$ (ANOVA) with Duncan's multiple range test.

Epididymal sperm count, alive sperm percent and sperm motility were significantly decreased $(\mathrm{P} \leq 0.05)$ in all treated groups as compared to the control. The reduction was more marked in rats treated with dermal low dose (Table 3). While there was noticed azospermia in the group treated dermally with high dose of the mixture. Sperm abnormalities were significantly increased $(\mathrm{P} \leq 0.05)$ in the treated groups compared to the control group. The elevation is more evident in the dermally low dose treated rats.

Serum testosterone and plasma cholinesterase BuChE levels

Table 4 showed that testosterone and plasma cholinesterase $\mathrm{BuChE}$ levels were significantly decreased $(\mathrm{P} \leq 0.05)$ in all treated groups compared to the control group. The greatest reduction was occurred in the dermally treated groups.

Table (4): Effect of the tested pesticides on serum testosterone and plasma cholinesterase

\begin{tabular}{|l|l|l|l|l|l|}
\hline \multirow{2}{*}{ Parameter } & \multicolumn{5}{|c|}{ Groups } \\
\cline { 2 - 6 } & Control & $\begin{array}{l}\text { oral low } \\
\text { dose }\end{array}$ & $\begin{array}{l}\text { oral high } \\
\text { dose }\end{array}$ & $\begin{array}{l}\text { dermal low } \\
\text { dose }\end{array}$ & $\begin{array}{c}\text { Dermal } \\
\text { high dose }\end{array}$ \\
\hline $\begin{array}{l}\text { Testosterone } \\
\text { (ng /m) }\end{array}$ & $2.90 \pm .27 \mathrm{~d}$ & $\begin{array}{l}2.22 \pm .29 \\
\mathrm{c}\end{array}$ & $\begin{array}{l}1.89 \pm .52 \\
\mathrm{bc}\end{array}$ & $1.66 \pm .44 \mathrm{ab}$ & $1.37 \pm .4 \mathrm{a}$ \\
\hline BuChE (U/L) & $\begin{array}{l}403.50 \pm \\
18.57 \mathrm{~d}\end{array}$ & $\begin{array}{l}223.25 \pm \\
38 . \mathrm{c}\end{array}$ & $\begin{array}{l}183.82 \pm \\
8.1 \mathrm{~b}\end{array}$ & $\begin{array}{l}139.88 \pm 8.4 \\
\mathrm{a}\end{array}$ & $\begin{array}{l}153.92 \pm 12.3 \\
\mathrm{a}\end{array}$ \\
\hline
\end{tabular}

All values are expressed as mean \pm S.E. Values with different letters at the same raw are significantly different at $\mathbf{P} \leq \mathbf{0 . 0 5}$ (ANOVA) with Duncan's multiple range test. 


\section{Genotoxic effects}

Table (5): Effect of the tested pesticides on sperm DNA by COMET test

\begin{tabular}{|c|c|c|c|c|}
\hline \multirow{2}{*}{ Parameter } & \multicolumn{3}{|c|}{ Groups } \\
\cline { 2 - 5 } & control & oral low dose & oral high dose & $\begin{array}{c}\text { dermal low } \\
\text { dose }\end{array}$ \\
\hline $\begin{array}{c}\text { Composite } \\
\text { score } \\
\text { (mean } \pm \text { SD })\end{array}$ & $17.00 \pm 8.19$ a & $130.33 \pm 51.00 \mathrm{~b}$ & $\mathbf{1 8 9 . 0 0} \pm 43.5 \mathrm{c}$ & $\mathbf{1 8 4 . 0 0 \pm 5 2 . 2 \mathrm { c }}$ \\
\hline
\end{tabular}

All values are expressed as mean \pm S.E. Values with different letters at the same raw are significantly different at $\mathbf{P} \leq \mathbf{0 . 0 5}$ (ANOVA) with Duncan's multiple range test.

DNA fragmentation in rats sperm DNA induced by each type of treatments was shown in Table (5) and images of the different degrees of DNA fragmentation obtained from our results are illustrated in figures $(\mathbf{1 , 2 , 3 , 4 , 5 )}$ The obtained results of the orally(low\&highdosing) and dermally low dose treated rats showed significant increase $(\mathrm{P} \leq 0.05)$ in $\mathrm{DNA}$ fragmentation expressed as composite score which represent tail length and DNA percentage in the tail. While the rats treated dermally with high dose $(1 / 20$ LD50) showed a zospermia except only in 2 rats where few spermatides were detected (results not shown).

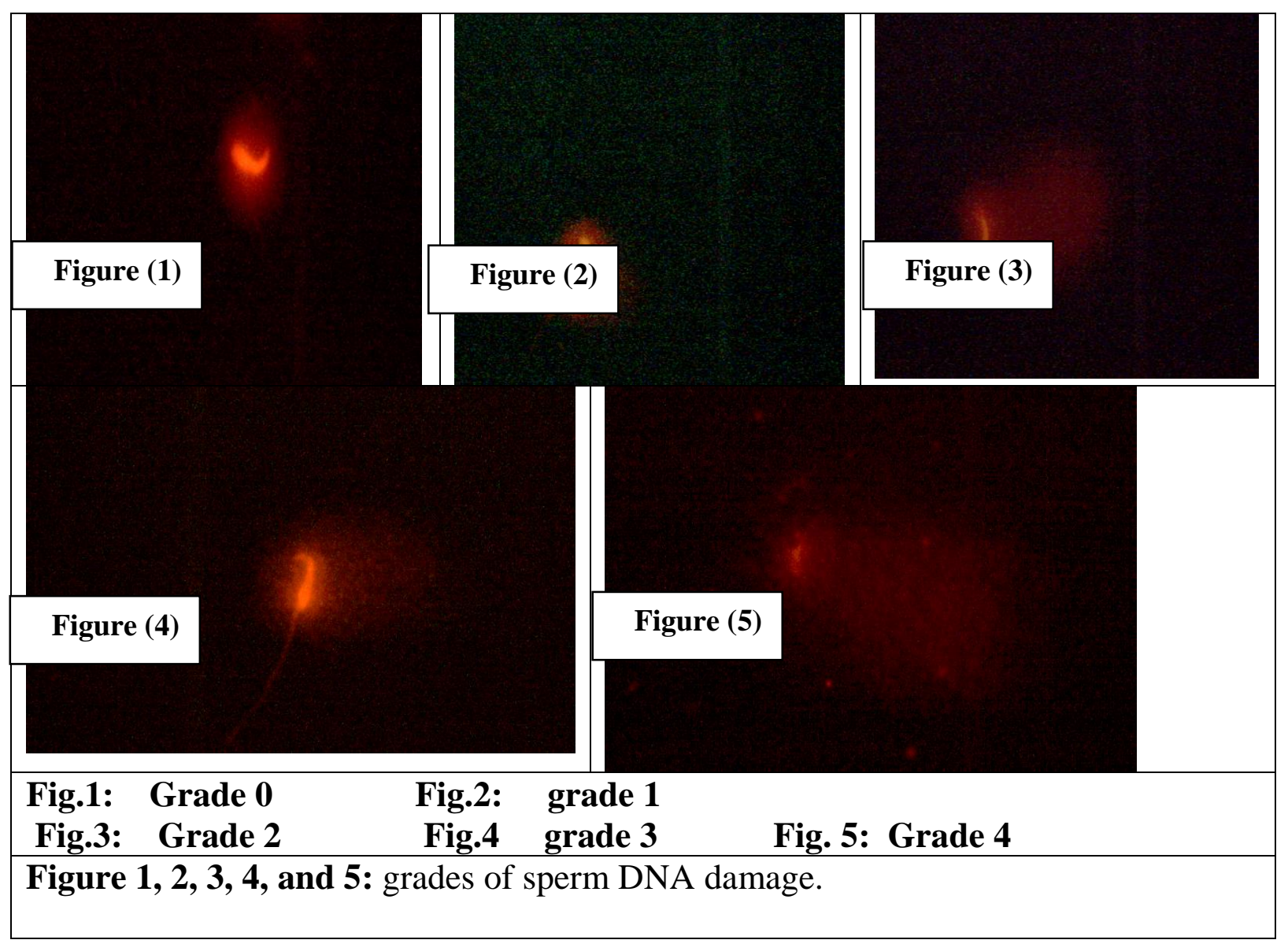


Histopathological Findings:

Testis:1) Macroscopically: the testes

of the treated groups showed varied degrees of congestion and atrophy in a dose and route dependent manner.

2) Microscopically, sections of control groups testes, showed densely packed seminiferous tubules that lined with stratified germinal epithelium with sperms in their lumens and leydig cells clusters in the interstitial spaces (Fig.6). Sections from the low oral dose treated rats, revealed mild to moderate distortion as well as degenerative and necrotic changes of tubular epithelial lining in some seminiferous tubules (ST) . In addition to, peritubular blood vessels, vascular wall thickening and congestion were also noticed (Fig .7). However, In high dose orally treated group, focal areas of coagulative necrosis and hyalinization appeared as eosinophilic mass within some tubules and interstitial tissue (Fig .8). Moreover focal interstitial oedema and vacuolar degeneration of the interstitial lyding cells were also noticed (Fig.9). At low dose dermally treated group, most tubules revealed degenerative changes and sloughing of most spermatogonial cell layers showed abnormal spermatogenesis with appearance of multineucleated giant spermatids cells within their lumen
(Fig.10).Other sections showed cytoplasmic vacuolar degeneration of most spermatogonic cell layers with thickening of regressed tubular wall (Fig.11). Meanwhile, at high dose dermally treated group, most of tubules showed sever regression and coagulative necrosis of spermatoginic cell layers that exfoliated within the lumen forming homogenous eosinophilic debris resulting in tubular atrophy with aspermatogenisis (Fig.12).

Epididymis: Microscopically, orally treated groups revealed dose dependant varied degrees of sperm reserve reduction, vacuolar degeneration of tubular epithelium, interstitial oedema as well as vascular congestion, lymphocytic infiltrations and fibrosis (Fig.13). While in low dose dermally treated groups, there were sever reduction of tubular sperm reserve reaching to absence of sperm reserve in high dose dermally treated group (Fig.14).

(B) Fibrosis: Masson trichrome stained sections showed marked increase in the connective tissue peri tubular and perivascular in both testis and epididymis as well as pronounced fat infiltration in seminal vesicles (SV) (Fig

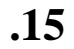

\&16) 


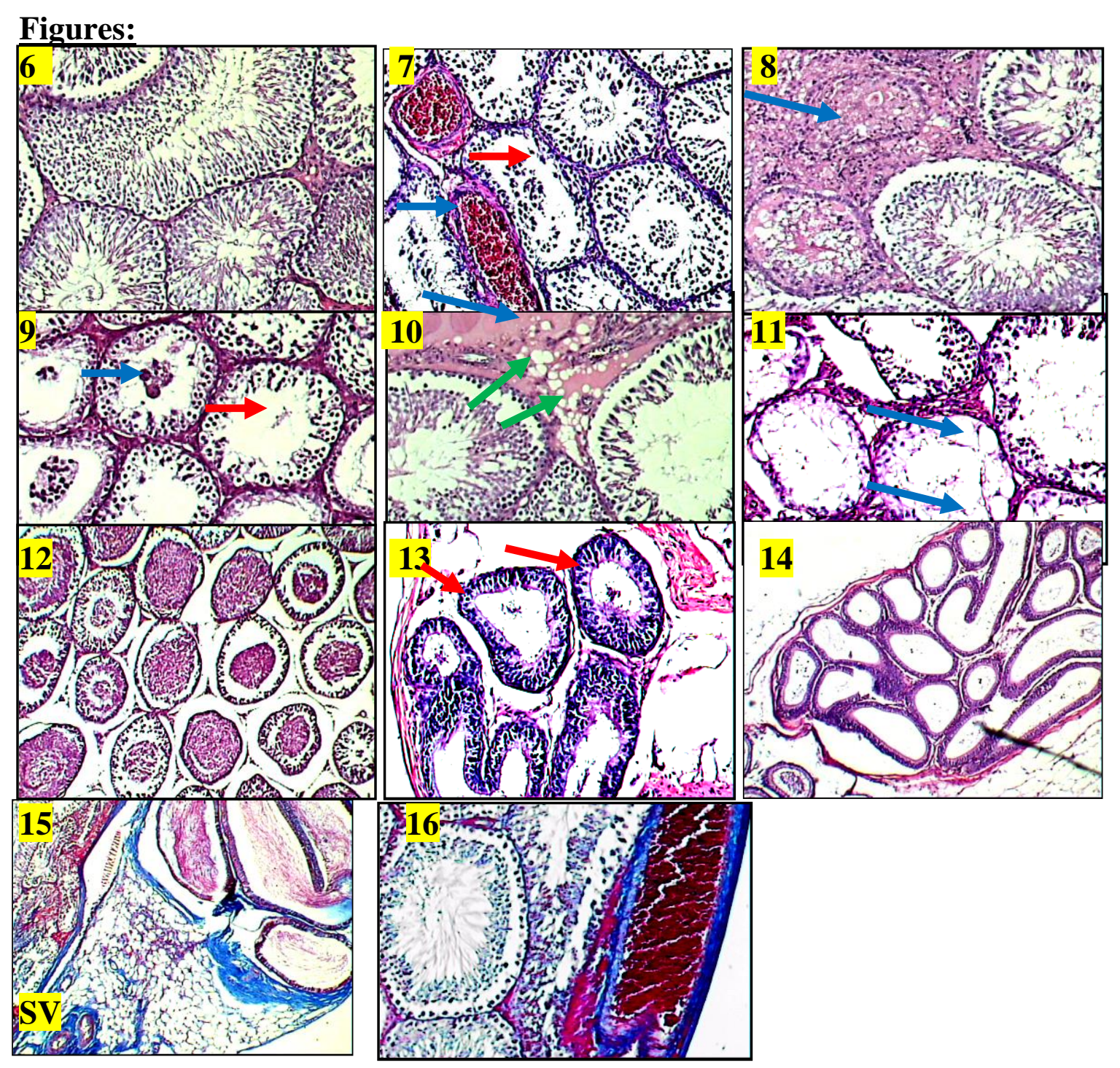

Figure (6): testis of control rat showed densely packed seminiferous tubules with their testicular parenchyma and little interstitium, with presence of sperm in the lumen (H\&E stain $\mathrm{x} 10)$.

Figure (7): Testis of low oral treated rat, showed moderate peritubular vascular congestion, wall thickening, and hyalinization (blue arrow). Tubular distortion, sloughing of degenerated germ cells within lumen (red arrow) (H\&E stain x 10)

Figure (8): Testis of high oral treated rat, showed focal eosinophilic areas of coagulative necrosis within degenerated tubules and interstitial tissue (blue arrow) (H\&E stain x 10).

Figure (9): Testis of high oral treated showed sever degeneration, vacuolation and separation of tubular spermatogineal cells in most of tubules with appearance of multineucleated giant spermatids cells within the tubular lumen (blue arrow) and sloughing of degenerated germ cells within lumen (red arrow) (H\&E stain x 10).

Figure (10): Testis of high oral treated rat, showed focal interstitial oedema and hyalinization $\mathbf{H}$ (blue arrow) and vacuolar degeneration of the interstitial leydig cells (green arrow) (H\&E stain x 10).

Figure (11): Testis of low dermal treated rat, showed complete loss of spermatogonial 
layers in many tubules and vacuolation (blue arrow) (H\&E stain x 4).

Figure (12): Testis of high dermal treated rats showed severs regression and coagulative necrosis in most of tubules (H\&E stain $\mathrm{x} 4$ ).

Figure (13): Epididymis of high oral rat showing epithelial lining vacculations (red arrow), loss of cilia, oedema and fibrosis also noticed. (H\&E stainx10).

Figure (14): Testis of high dermal treated rats showing epididymis with absence of sperm reserve and tubular wall and vascular thickening . (H\&E stainx4).

Figure (15): Testis of high oral treated rats showing pronounced fat infiltration in seminal vesicles (SV) with increased the of tunica albuginea, peritubular blood vessels and epididymis as blue collagen fibers (Masson-trichrome stain $\mathrm{x} 4$ )

Figure (16): Testis of high dermal treated rats showing increase thickness, fibrosis of tunica albuginea, peritubular blood vessels as blue connective tissue fibers (Masson-trichrome stain x10)

\section{Histomorphometric analysis:}

Table (6): Histomorphometric analysis including the measurements parameters for seminiferous tubule (ST) epithelium, ST diameter, tubular lumen, blood vessels and epithelial height

\begin{tabular}{|c|c|c|c|c|c|}
\hline \multirow{2}{*}{$\begin{array}{c}\text { Parameter* } \\
\text { Measurement }(\mu \mathrm{m})\end{array}$} & \multicolumn{5}{|c|}{ groups } \\
\hline & Control & $\begin{array}{c}\text { oral low } \\
\text { dose }\end{array}$ & $\begin{array}{l}\text { oral high } \\
\text { dose }\end{array}$ & $\begin{array}{l}\text { dermal } \\
\text { low dose }\end{array}$ & $\begin{array}{c}\text { Dermal } \\
\text { high dose }\end{array}$ \\
\hline ST epithelium $(\mu \mathrm{m})$ & $\begin{array}{l}285.4 \pm \\
5.3 \mathrm{a}\end{array}$ & $\begin{array}{l}210.9 \pm \\
0.7 \mathrm{~b}\end{array}$ & $\begin{array}{l}198.9 \pm \\
0.7 b\end{array}$ & $\begin{array}{l}192.9 \pm \\
2.8 b\end{array}$ & $\begin{array}{l}174.5 \pm \\
17.9 c\end{array}$ \\
\hline $\begin{array}{l}\text { Epithelium height } \\
(\mu \mathrm{m})\end{array}$ & $\begin{array}{l}174.3 \pm \\
3.6 \mathrm{a}\end{array}$ & $\begin{array}{l}162.3 \pm \\
6.6 \mathrm{~b}\end{array}$ & $\begin{array}{l}153.9 \pm \\
7.3 \mathrm{~b}\end{array}$ & $\begin{array}{l}150.9 \pm 6.3 \\
b\end{array}$ & $\begin{array}{l}138.0 \pm 6.4 \\
c\end{array}$ \\
\hline Lumen $(\mu \mathrm{m})$ & $\begin{array}{l}27.6 \pm \\
5.9 \mathrm{a}\end{array}$ & $\begin{array}{l}25.0 \pm \\
8.0 \mathrm{a}\end{array}$ & $\begin{array}{l}21.0 \pm \\
7.0 \mathrm{~b}\end{array}$ & $13.8 \pm 2.2 \mathrm{c}$ & $12.9 \pm 2.0 \mathrm{c}$ \\
\hline ST diameter $(\mu \mathbf{m})$ & $\begin{array}{l}447.6 \pm \\
8.0 \mathrm{a}\end{array}$ & $\begin{array}{l}437.4 \pm \\
3.0 \mathrm{~b}\end{array}$ & $\begin{array}{l}430.5 \pm \\
11.4 b\end{array}$ & $\begin{array}{l}429.5 \pm \\
11.2 \mathrm{c}\end{array}$ & $\begin{array}{l}423.9 \pm 7.1 \\
c\end{array}$ \\
\hline $\begin{array}{l}\text { Blood vessel wall } \\
(\mu \mathrm{m})\end{array}$ & $\begin{array}{l}3.6 \pm \\
0.4 \mathrm{a}\end{array}$ & $\begin{array}{l}5.8 \pm 0.9 \\
b\end{array}$ & $\begin{array}{l}6.9 \pm 0.9 \\
c\end{array}$ & $7.8 \pm 3.6 \mathrm{c}$ & $6.9 \pm 1.3 \mathrm{c}$ \\
\hline Sertoli cell $\left(\times 10^{6}\right)$ & $\begin{array}{l}61.74 \\
\pm 1.19 \text { a }\end{array}$ & $\begin{array}{l}54.38 \pm \\
2.53 \mathrm{~b}\end{array}$ & $\begin{array}{l}50.60 \pm \\
1.09 \mathrm{~b}\end{array}$ & $\begin{array}{l}49.56 \pm \\
2.5 b\end{array}$ & $\begin{array}{l}42.66 \pm 1.5 \\
c\end{array}$ \\
\hline
\end{tabular}

Values are the mean \pm SEM; Different letters above the bars denote a statistically significant difference between groups $(P<0.05)$.

The histomorphometric analysis of the treated rat testes revealed significant reductions in height of germinal epithelium, height of ST epithelium, ST diameter and sertoli cell numbers in all treated groups compared to the control and there was significant increase of blood vessel wall thickness denoting starting fibrosis which may adversely affect on spermatogenesis reaching to testicular atrophy with marked a spermatogenesis in a dose and rout depending manner as showed in Table (6). 


\section{DISCUSSION}

This study was conducted to evaluate the effect of chloropyrifos and cypermethrin mixture on male reproductive organs weight, sperm characteristics, serum testosterone, genotoxic effect, and histopathology and histomorphometric alterations. The tested pesticide mixture (chlorpyrifos \&cypermethrin) has increased toxicity than does the individual compounds. The oral LD50 of chlorpyrifos \&cypermethrin for rats are (135-163) and (250-4150) $\mathrm{mg} / \mathrm{kg}$ respectively Pesticides Manual, (2004). The estimated acute oral LD50 of the tested formulation was $85.16 \mathrm{mg} / \mathrm{kg}$. Also dermal LD50 of chlorpyrifos or cypermethrin for rats is more than 5000 $\mathrm{mg} / \mathrm{kg}$ Pesticides Manual, (2004). the estimated dermal LD50 is 2125.03 $\mathrm{mg} / \mathrm{kg}$. So it is clear that the mixture of pesticides have synergistic effect of toxicity. These results are in agreement with Barata et al. (2004).

The results of the present study showed significant inhibition in plasma cholinesterase $(\mathrm{BuChE})$ in the treated groups since chloropyrifos (OP) one of the ingredients composing the tested formulation. This is in support with katta, (2008). who reported biological marker such as monitoring of serum cholinesterase and cholinesterase enzymes in red blood cells (RBC) can detect actual exposure to pesticides particularly organophosphates. Also these results are in agreement with Bushnell et al. (1994) who recorded that subcutaneous injection of chlorpyrifos inhibited ChE activity by $60 \%$ to $90 \%$. In addition, Plasma $\mathrm{BuChE}$ is more sensitive to OP exposure than RBC AChE Khan et al. (2008).

Organ weight is a fundamental benchmark for the toxicological studies Yavasoglu et al. (2008) Our study showed significant reduction $(\mathrm{P} \leq 0.05)$ of the reproductive organ weights (testis, epidedymis and accessory sex glands) compared to control animals especially in the dermally treated groups which could be attributed to the decrease in serum testosterone level. The weight of the testis is essentially dependent on the mass of the differentiated spermatogenic cells; the reduction in the weight of the testis may be due to decreased number of germ cells, inhibition of spermatogenesis and steroidogenic enzyme activity Mosbah et al. (2008) These results are in agreement with the findings of Mosbah et al. (2008) Who reported reduction in testes, epididymis and Seminal vesicles weights in rats treated with the highest dose of lorspan. And Anderson et al. (2002) who mentioned that weight testes of rats treated by DLM showed reduction at the dose of $4.0 \mathrm{mg} / \mathrm{kg}$ bwt from day 1 of pregnancy to day 21 of lactation.

Our study revealed that rats treated with the tested formulations had markedly impaired sperm quality. Since, the tested formulations significantly lowered sperm count, sperm motility and alive sperm percent and significantly increased sperm abnormalities in all treated groups $(\mathrm{P} \leq 0.05)$ especially in the dermally treated group moreover, in the group treated dermally with high dose of the mixture we found only 2 rats had few spermatide numbers (results not shown) while the rest of the group showed complete azoospermia. The observed decrease in semen characteristics could be explained by the fact that the tested pesticides acted directly on the testes and affected the 
androgen biosynthesis pathway which regulates the function of testes weight, secretoryfunction of epididymes, seminal vesicles Moreover, a lack of testosterone disrupts spermatogenesis as Testosterone is essential to maintain the structure and function of the testis and male accessory sex gland Broockfor \& Blake (1997).

The reduction in sperm count was consistent with changes in epididymal weights. These findings are in agreement with the findings conducted by Mosbah et al. (2008) who stated that lorsban at dose $15 \mathrm{mg} / \mathrm{kg} / \mathrm{bw}$ caused a significant decrease in all sperm parameters in the treated rats compared with the control animals. Also our results are in accordance with Odaa\&, Zeynab (2012).

One of the indicators of the chemical toxicity affecting the reproductive system is the decreased level of testosterone Yoshida et al. (2002). the pesticides mixture treated rats had a significant reduction $(\mathrm{P} \leq 0.05)$ in serum testosterone level compared to the control group which was more pronounced in the dermally treated groups. The study of Banbino \& Hsueti (1981) suggested an interaction of pesticides with hypothalamo-pituitary gonadal axis which control spermatogenesis and may also interfere directly with sertoli or leydig cells responsible for production of proteins involved in the transport and the synthesis of testosterone. The observed reduction in serum testosterone concentrations is in agreement with the findings obtained by Elbetieha et al. (2001) and Yousef et al. (2003) who found that serum level of testosterone, folllicule stimulating hormone and luteinzing hormone showed significant reduction in male rats and rabbits treated by cypermethrin.

Genotoxic effects are considered among the most serious of the possible health effects of agricultural chemicals Gabbianelli et al. (2002). This study showed significant increase of comet parameters represented by composite score (tail length, DNA percentage in tail) compared with the control group in all treated groups (except in the group treated with high dermal dose in which comet test not done due to complete a zospermia) . Atessahin et al. (2005) reported that oxidative damage induced by pyrethroids might be due to their lipophylic character, so it can penetrate easily to the cell membrane and cause membrane lipid peroxidation. Moreover, cypermethrin has both a vinyl and a dimethylcyclopropane group. Dimethylcyclopropane may be oxidized into methyl butenol. If the vinyl group and/or the methyl butenol group undergo epoxidation, the resultant active metabolites may cause DNA damage Sankar et al. (2010).

Macroscopically noticed changes in this study are similar to those observed by El-Deeb et al. (2007)and Nagda \& Bhatt, (2011) who attributed the testicular congestion, oedema and atrophy to the effect of oxidative stress damage evoked by pesticide due to overproduction of reactive oxygen species that damage the vital cell components, in this respect, Abdallah et al. (2010) mentioned that testicular atrophy could be explained by the fact that testicular weight is essentially dependent on the mass of the differentiated spermatogenic cells, the reduction in the weight of the testis may be due to decreased number of germ cells, inhibition of 
spermatogenesis this result was in agreement with Abdallah et al. (2010) and Saber \& Al-Amoudi, (2012).

microscopically observed testicular and epidedymal lesions as distortion, vacuolations, degenerations as well as occurrence of multinucleated giant cells in the lumen that observed in our study were similar to those observed by El-Deeb et al. (2007) ; Nagda \& Bhatt, (2011) ; Suresh et al. (2011) Who were attributed to the direct cytotoxic effect of the tested pesticide which induce oxidative stress on the seminiferous tubules, through generation of free oxygen radicals, alteration in antioxidants,lipid peroxidation which leads to cytotoxicity and genotoxicity. Also the tested pesticide had indirect effect on testicular blood vessels, which causes vascular stasis in addition to inhibition of overall hormonal control mechanism at either the gonadal or the hypothalamic pituitary levels. Moreover, the induction of acid phospahatase enzyme activity due to the peri tubular vascular dilatation leading to increase of cell membrane permeability and transphosphorylation disturbance resulting from cellular degeneration that causing inhibition of spermatogenesis which proved by tubular degenerations and marked fibrosis which is the end result of an inflammatory process and cell death Azza, (2010) \& Idris et al. (2012).

Testicular histomorphometric analysis in the present study revealed that the tested pesticide mixture induced significant reductions in height of germinal epithelium, lumen and diameter of ST which explained by damage of germinal cell layers. That it was reported previously by Aiad et al. (2008) Findings of histomorphometric analysis support previously described histopathological alterations in ST resulting in tubular degeneration, atrophy,significant deluminization of the seminiferous tubules and arrested of spermatogenesis. Batra et al.(2004); Saiful \& Mizanul, (2015) and Ikpeme et al. (2016).

\section{CONCLUSION}

The present study concluded that, the tested pesticides mixture (chloropyrifos \&cypermethrin) induced significant reproductive toxicity and endocrinal disruption effects as well as histopathological alterations the aforementioned adverse effects were more obvious during the dermal exposure indicating that dermal exposure is more hazardous than oral exposure and necessitating the application of intensive safety programmes \&precautions during handling and spraying of pesticides besides the usage of personal protective equipments.

\section{REFRENCES}

Abdallah FB, Slima AB, Dammak I, Keskes-Ammar $\mathbf{L}$ and Mallek $Z$ (2010): Comparative effects of dimethoate and deltamethrin on reproductive system in male mice. Andrologia. 42(3):182.

Aiad, H.; Abdou, A.; Bashandy, M.; Said A.; Ezz- Elarab, S. and Zahran, A. (2008): Computerized nuclear morphometry in diagnosis of thyroid lesions with predominant follicular pattern. J. Egyp Soc. Path.28 (1),june: 105-13.

Ambali SF, Aliyu MB (2012). Shortterm sensorimotor and cognitive changes induced by acute chlorpyrifos exposure in Wistar 
rats: Ameliorative effect of vitamin E. Pharmacology 3:31-38.

Anderson JMA, Samanta AU, Gladys MS,Masahiko O, Paulo RD. (2002):Reproductive effects of deltamethrin on male offspring of rats exposed during pregnancy and lactation. Regul Toxicol Pharmacol; 36:310-7.

Atessahin A, Yilmaz S, Karahan I, Tasmedir PB (2005): The effects of vitamin $E$ and selenium on cypermethrin induced oxidative stress in rats. Turk J Vet Anim Sci 29:385-391.

Azza, M. Gawish. (2010): TheProtective Role of Alpha LipoicAcid Against pesticides Induced testicular toxicity. (Histopathological and Histochemical Studies) Life Science Journal, Vol 7, No 3, September.

Banbino, T.H., Hsueh, A.J.W. (1981): Direct inhibitory effect of glucocorticoids upon testicular luteinizing hormone receptor and steroidogenesis in vivo and in vitro, Endocrinology, vol.108,, p.21422151.

Barata, C., Solayan, A, Porte C. 2004: Role of B-esterases in assessing toxicity of organophosphorus (chlorpyrifos, malathion) and carbamate (carbofuran) pesticides to Daphnia magna. Aquat Toxicol 66:125-139.

Batra, N., B. Nehru and M.P. Bansal, (2004): Reproductive potential of male portan rats exposed to various levels of lead with regard to Zinc status. Br. J. Nutr., 91: 1887-1891.

Bearden H, Fuqua Bearden $H$, Fuquary 1980: J. Applied reproduction. Reston, Virginia: Reston Publishing Co. Inc; 158160.
Bolognesi,. C (2003): Genotoxicity of pesticides: a review of human biomonitoring studies. Mutat. Res, 543(3): 251-272.

Broockfor FR, Blake CA. (1997):Chronic administration of 4tert-octylphenol to adult male rats causes shrinkage to the testes and male accessory sex organs, disrupts spermatogenesis, and increases the incidence of sperm deformities. Biol Reprod 57:267-77.

Bushnell P.J., Kelly K.L., and Ward T.R. (1994): Repeated inhibition of cholinesterase by chlorpyrifos in rats: behavioral, neurochemical and pharmacological indices of tolerance. J Pharmacol Exp Ther, 270:15-25.

Chauhan, L.K.; Chandra, S. P.; Saxena, S.N.; Gupta, S.K. (2005): In vivo cytogenetic effects of a commercially formulated mixture of cypermethrin and quinalphos in mice, Mutat. Res. 587 120-125.

Clermont Y, Harvey SC. 1965: Duration of the seminiferous epithelium of normal, hypophysectomized and hypophysectomized hormone treated albino-rats. Endocrinology;79:80-9.

Codrington, A.M., Hales, B.F. and Robaire, B. (2004): Spermiogenic germ cell phase-specific DNA damage following cyclophosphamide exposure. J. Androl. 25:354-362.

Collins, A.R., Ma, A.G. and Duthie, S.J. (1995): The Kinetics of repair of oxidative DNA damage (strand breaks and oxidized pyrimidines) in human cells. Mut. Res., 336: 69-77.

Committee on Toxicity of Chemicals (2002): Risk CAssessment of Mixtures of Pesticides and Similar 
Substances.

19.DeLorenzo, M.E., Serrano, L.(2003): Individual and mixture toxicity of three pesticides; atrazine, chlorpyrifos, and chlorothalonil to the marine phytoplankton species Dunaliella tertiolecta, J. Environ. Sci. Health 5 529-538.

Demetrious JA. (1987): Testosterone in methods. In: Kapalan LA, editor. Clinical chemistry tech AG. 2nd ed. CVMOS Co.;. p. 268.

Eaton DL, Daroff RB, Autrup H, Costa LG, Coyle J, Mckhann G, Mobley WC, Nadel L, Nubert D, Schukte-Hermann R, Peter S, Spencer PS (2008): Review of the toxicology of chlorpyrifos with emphasis on human exposure and neurodevelopment. Crit. Rev. Toxicol. S2:1-125.

Elbetieha, A. S.I., Khamas, H. Da'as, Darmani, W. (2001)Evaluation of the toxic potentials of cypermethrin pesticide on some reproductive and fertility parameters in the male rats, Arch. Environ. Contam. Toxicol., vol.41, p.522-528.

El-Deeb, A.E.; Abd El-Aleem, I.M. and Sherin, S.Ghaleb (2007): Harmful effect of some insecticides on vital parameters of albino rats. J. Egypt. Soc. Toxicol. (Vol. 36: 5360 Jan.

Ellman G.L., Courtney K.D., Anders V.J.R., Featherstone R.M. (1961): A new rapidcolorimetric determination of acetylcholinesterase activity, Biochem. Pharmacol. 7: 88-95.

Endocrine Disruptor and Testing Advisory Committee (EDSTAC). (1998): Final Report, [EPA/743/R98/003].

Evans G, Maxwell WMC. (1987):

Handling and examination of semen. In: Maxwell WMC, editor. Salamon's artificial insemination of sheep and goats. Sydney, Australia: Butterworths;. p. 93.

Galloway, T. and Handy, R. (2003): Immunotoxicity of organophosphorus pesticides. Ecotoxicology 12: 345-363.

Gabbianelli R, Nasuti C, Falcioni G, Cantalamessa F (2002):

Cypermethrin-induced plasma membrane perturbation on erythrocytes from rats: reduction of fluidity in the hydrophobic core and in glutathione peroxidase activity. Toxicololgy 175:91-101.

Haines, G., Marples, B., Daniel, P. and Morris, (1998): DNA damage in human and mouse spermatozoa after in vitro-irradiation assessed by the comet assay, in: Reproduction Toxicology, ed, J. del MAzo, plenum Press. New York.

Idris, S B.; Ambali, SF. and Ayo, J.

O (2012): Cytotoxicity of chlopyrifos and cypermethrin: The ameliorative effects of antioxidants African Journal of Biotechnology Vol. 11(99), pp. 16461-16467, 11 December.

Ikpeme E.V.; Okonko L.E. and Udensi O.U. (2016): Detrimental Effects of Chlorpyrifos and Cypermethrin on Reproductive Physiology of Male Albino Rats Research Journal of Environmental Toxicology Res.J. Environ. Toxicol., 10 (1): 68-74.

Jintana S., Sming K., Krongtong Y., Thanyachai S. (2009): Cholinesterase activity, pesticide exposure and health impact in a population exposed to organophosphates, Int. Arch. Occup. Environ. Health 82: 833842. 
John H Ross, Jeffrey H Driver, Roger C Cochran, Thomas Thongsinthusak, Robert I Krieger(2001): The Annals of Occupational Hygien, Volume 45, Supplement 1, April Pages S5-S17 .

Kata, F.S. (2008): Effect of dichlorvos pesticide on fertility of laboratory male mice Mus musculus. Basrah Journal of Veterinary Research. 7(1): 1-10.

Khan DA, Bhatti MM, Khan FA, Naqvi ST, Karam A. (2008): Adverse effects of pesticides residues on biochemical markers in Pakistani tobacco farmers. Int J Clin Exp Med.;1(3):274- 282.

Latuszynska J, Luty S, Raszewski G, Tokarska-rodak M, Przebirowska D, Przylepa E, Haratym-maj A (2001): Neurotoxic effect of dermally-applied chlorpyrifos and cypermethrin in Wistar rats. Ann. Agric. Environ. Med. 8:163-178.

Matousek J. (1969): Effect on spermatogenesis in guinea pigs, rabbits and sheep after their immunization with sexual fluid of bulls. J Report Fert; 19:63-72.

Mehta A., Verma R.S., Srivastava N. (2008): Oxidative DNA damage induced by chlorpyrifos in rat tissues, Environ. Mol. Mutagen. 49: 426-433.

Mosbah Rachid, Amel Chouabia, Mokhtar Ibrahim Yousef, Mohamed Salah Boulakoud (2008): Lorsban-induced changes in haematological parameters, testosterone and thyroxin levels, and semen quality of male rats Revue Synthèse $\mathrm{N}^{\circ} 18$, Juillet.

Nagda, G., and Bhatt, D.K., (2011): Alleviation of lindane induced toxicity in testis of Swiss mice (Mus musculus) by combined treatment with vitamin $\mathrm{C}$, vitamin $\mathrm{E}$ and $\alpha$-Lipoic acid. Ind. J. Exp. Bio. 49, 191-199.

Odaa, S. S.; Zeynab Kh. ElMaddawy. (2012): Protective effect of vitamin $E$ and selenium combination on deltamethrininduced reproductive toxicity in male rats Experimental and Toxicologic Pathology 64 813-819.

Ojha A., Yaduvanshi S.K., Srivastava N. (2011): Effect of combined exposure of commonly used organophosphate pesticides on lipid peroxidation and antioxidant enzymes in rat tissues. Pesticide Biochemistry and Physiology, 99 148-156.

Patel S., M Bajpayee, Pandey A.K., Parmar ., Dhawan A. (2007): In vitro induction of cytotoxicity and DNA strand breaks in $\mathrm{CHO}$ cells exposed to cypermethrin, pendimethalin and dichlorvos, Toxicol. In Vitro, 21: 1409- 1418.

Pesticides Manual (2004): The British Crop Protection Council (BCPC) Puplications Sales, Bear Farm, Binfield, Bracknell, Berks, and UK Phys. 94:55-59.

Power, L.E., Sudakin, D.L., (2007): Pyrethrin and pyrethroid exposures in the United States: a longitudinal analysis of incidents reported to Poison Centers. J. Med. Toxicol. 3, 94-99.

Ramos LM, Querejeta GA, Flores AP, Hughes EA, Zalts A, Montserrat JM. (2010): Potential dermal exposure in greenhouses for manual sprayers: analysis of the mix/load,application and re-entry stages. Sci Total Environ; 408:4062-8.

Repetto R, Baliga S. (1996): Pesticides and the immune system. 
The public health risks. World Resources Institute.

Saber A. Sakr ,Wael M. Al-Amoudi (2012): Effect of Ginger Extract on Deltamethrin Induced Histomorphological and Immunohistochemical Changes in Testes of Albino Rats. Life Science Journal;9(1).

Saiful Islam, M. and Mizanul Hoque, M. (2015): Clinico-haematological and histopathological features of the Swiss albino mice Mus musculus L. in response to chronic cypermethrin exposure Scholars .Academic Journal of Biosciences (SAJB) Sch. Acad. J. Biosci,3(5):421-428.

Sankar P., A.G. Telang, A. Manimaran, (2010): Curcumin protects against cypermethrininduced genotoxicity in rats, Environ. Toxicol. Pharmacol. 30 289-291.

Shadnia, M. Dasgar, S. Taghikhani, A. Mohammadirad, R. Khorasani, M.Abdollahi, (2007): Protective effects of alphatocopherol and $\mathrm{N}$-acetyl-cysteine ondiazinon-induced oxidative stress and acetylcholinesterase inhibition in rats,Toxicol. Mech. Methods 17 109-115.

Singh, N.P., Danner, D.B., Tice R.R., McCoy, M.T., Collins, G.D., and Schneider, E.L. (1989): Abundant alkali-sensitive sites in DNA of human and mouse sperm, Exp. cell. Res. 184: 461-470.

SöNnmez M, Türk G, Yüce A. (2005): The effect of ascorbic acid supplementation on sperm quality,lipidperoxidationandtestoste rone levelsofWistar rats. Theriogenology; 63:2063-72.

Suresh C. Joshi, Bhawna Bansal \&Nakuleshwar D. Jasuja (2011):
Evaluation of reproductive and developmental toxicity of cypermethrin in male albino rats.Toxicological \& Environmental Chemistry 93, 3.

Suvarna, Kim S.; Layton, Christopher; Bancroft, John D (2013): Bancroft's Theory and Practice of Histological Techniques, by Suvarna, 7th Edition Published by Churchill Livingstone.

Timchalk C, Poet TS, Hinman MN, Busby AL, Kousba AA (2005): Pharmacokinetic and pharmacodynamic interaction for a binary mixture of chlorpyrifos and diazinon in the rat. Toxicol. Appl. Pharm. 205:31-35.

Weil, C. S. (1952): Tables for convenient calculation of median effective dose (ED50 or LD50) and instructions in their use. Biometrics, 8: 249.

Yavasoglu A, Karaaslan MA, Uyanikgil Y, Sayim F, Ates U, Yavasoglu NU. (2008): Toxic effects of anatoxin-a on testes and sperm counts of male mice. Exp Toxicol Pathol 60:391-6.

Yokoi K, Uthus EO, Nielsen FH. (2003): Nickel deficiency diminishes sperm quantity and movement in rats. Biol Trace Elem Res; 93:141.

Yoshida M, Kitani T, Takenaka A, Kudoh K, Katsuda SI, Taya K,. (2002): Lack of effects of oxolinic acid on spermatogenesis in young male adult and aged Wistar rats. Food Chem Toxicol 40:1815-25.

Yousef, M.I El-Demerdash, F. M..; Al-Salhen, K. S. (2003) a: Protective role of isoflavones against the toxic effect of cypermethrin on semen quality and testosterone levels of rabbits, J. 
Environ. Sci. Health, vol. 38, issue 4B, 2003, p. 463-478.

Yousef M.I., El-Demerdash F.M., Kamel K.I., Al- Salhen K.S., (2003)a: Changes in some hematological and biochemical indices of rabbits induced by isoflavones and cypermethrin, Toxicology, 189: 223-234. 
الملخص العربي

السمية الإنجابية واختلال الغدد الصماء الناتج عن التعرض لخليط من المبيدات عن طريق الفم والجلد في ذكور الفئران

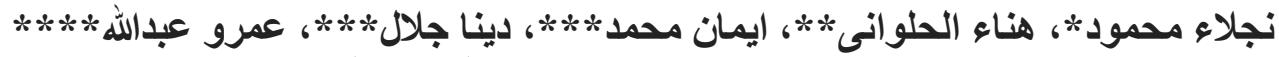

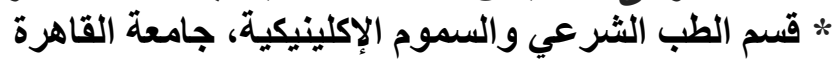

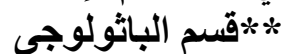

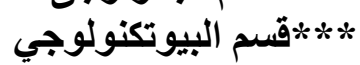

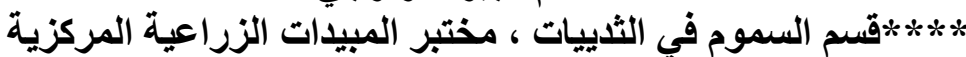

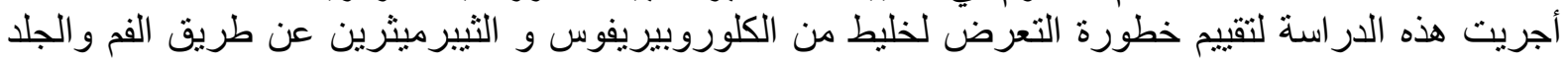
استنادا الى بعض القياسات الدالة على القدرة الانجابية و كفاءة الغدد الصماء اضافة الى التغيرات

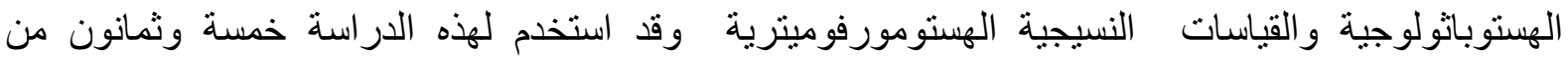

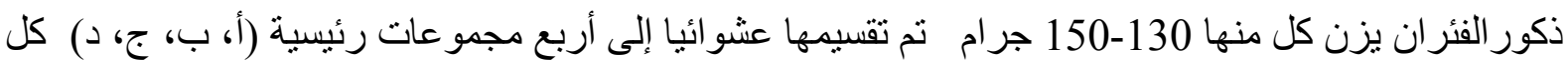

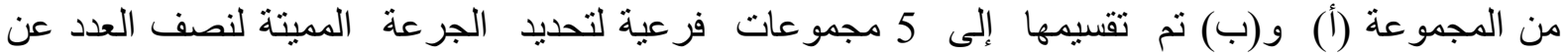

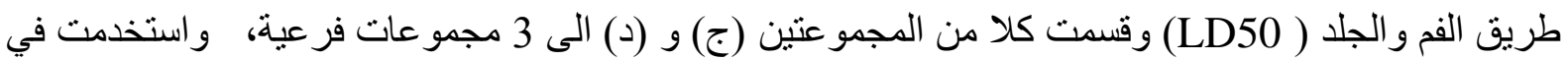

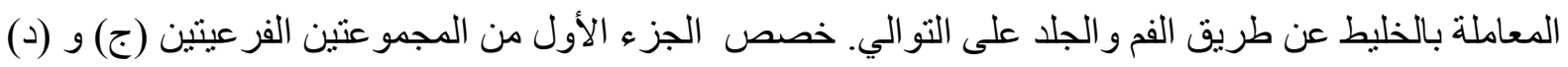
كمجموعة ضابطة وأعطيت المجموعتين الفرعيتين من المجموعة (ج) عن طريق الفيق الفم جرعنان 4.26

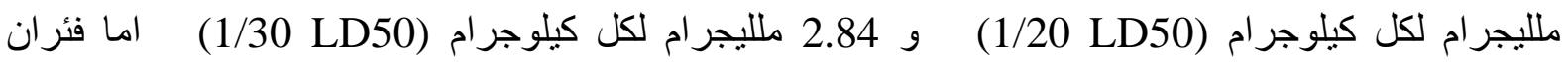
المجمو عتين الفرعيتين(د) عرضت عن طريق الجلد لجر عتين 70.85 ملليجر ام لكل كيلوجر ام (1/30 LD50 )

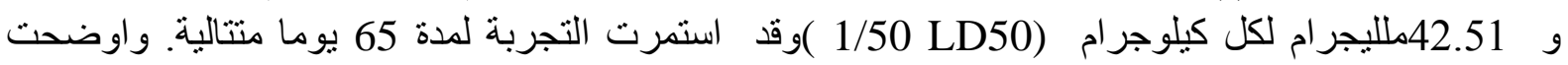

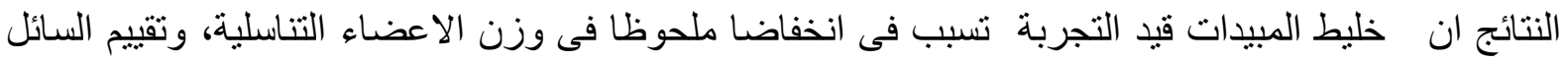

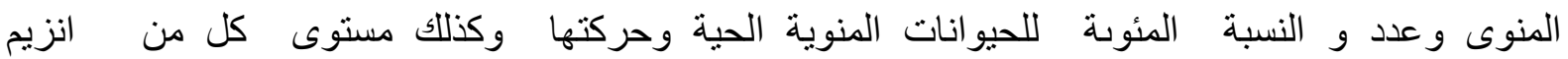

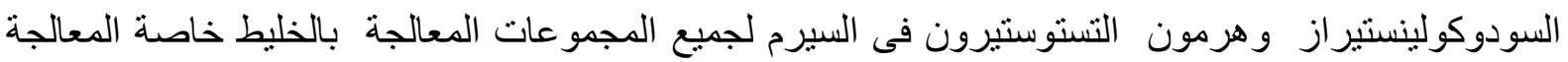

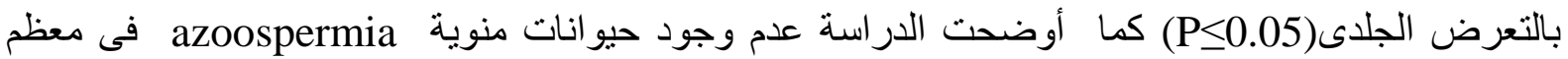

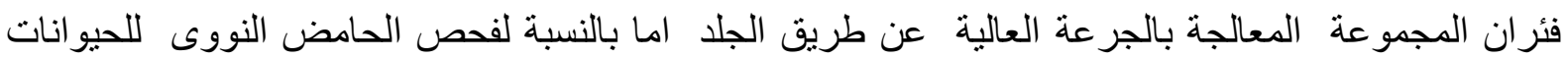

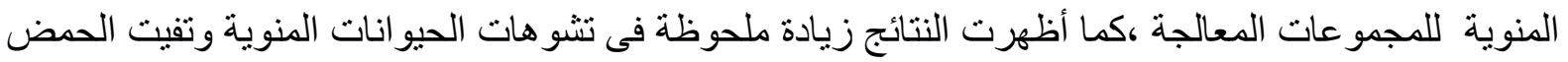

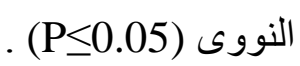

كما أظهر الفحص الهستوباثولوجى تغيرات منباينة من منوسطة الى شديدة فى أنسجة الخصية و البربخ طبقا

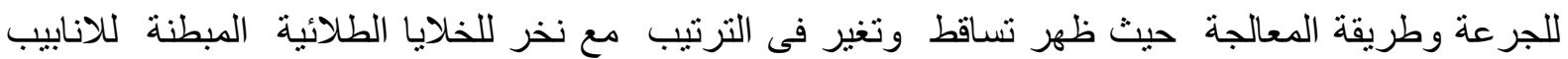

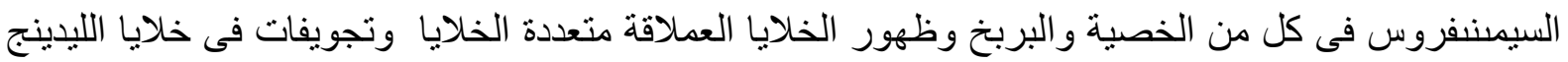

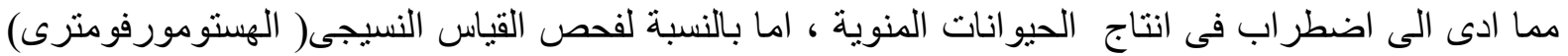

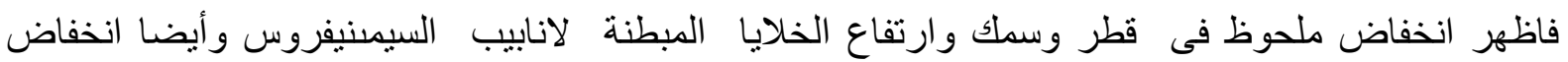

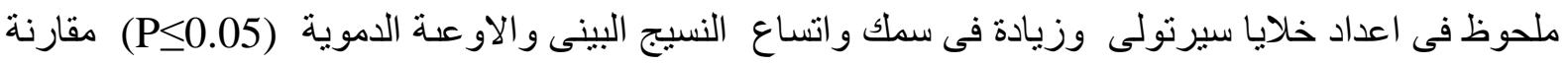

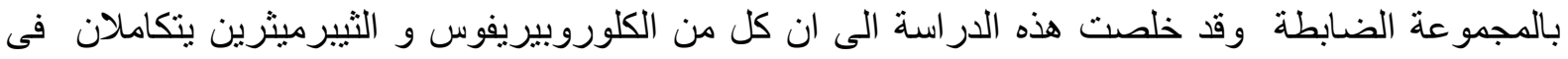

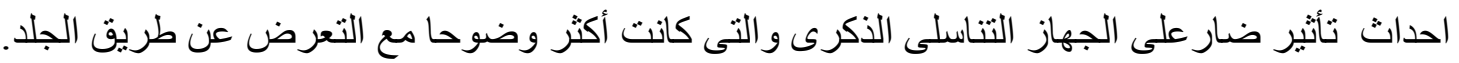

